\title{
Power Consumption: Base Stations of Telecommunication in Sahel Zone of Cameroon: Typology Based on the Power Consumption-Model and Energy Savings
}

\author{
Albert Ayang, ${ }^{1}$ Paul-Salomon Ngohe-Ekam, ${ }^{2}$ Bossou Videme, ${ }^{3}$ and Jean Temga ${ }^{4}$ \\ ${ }^{1}$ Higher Institute of the Sahel, Department of Renewable Energy, University of Maroua, P.O. Box 46, Maroua, Cameroon \\ ${ }^{2}$ National Advanced School of Engineering, Energy and Automatic Laboratory, University of Yaounde I, \\ P.O. Box 8390, Yaounde, Cameroon \\ ${ }^{3}$ Higher Institute of the Sahel, Department of Information and Telecommunication, University of Maroua, \\ P.O. Box 46, Maroua, Cameroon \\ ${ }^{4}$ Ecole Polytechnique Montreal, Polygrames Laboratory, P.O. Box 2500, Chemin Montreal, M6106, Canada H3T1J4
}

Correspondence should be addressed to Albert Ayang; ayabache@yahoo.fr

Received 6 April 2016; Revised 31 May 2016; Accepted 1 June 2016

Academic Editor: Mattheos Santamouris

Copyright (C) 2016 Albert Ayang et al. This is an open access article distributed under the Creative Commons Attribution License, which permits unrestricted use, distribution, and reproduction in any medium, provided the original work is properly cited.

In this paper, the work consists of categorizing telecommunication base stations (BTS) for the Sahel area of Cameroon according to their power consumption per month. It consists also of proposing a model of a power consumption and finally proceeding to energy audits in each type of base station in order to outline the possibilities of realizing energy savings. Three types of telecommunication base stations (BTS) are found in the Sahel area of Cameroon. The energy model takes into account power consumption of all equipment located in base stations (BTS). The energy audits showed that mismanagement of lighting systems, and of air-conditioning systems, and the type of buildings increased the power consumption of the base station. By applying energy savings techniques proposed for base stations (BTS) in the Sahel zone, up to 17\% of energy savings are realized in CRTV base stations, approximately $24.4 \%$ of energy are realized in the base station of Missinguileo, and approximately $14.5 \%$ of energy savings are realized in the base station of Maroua market.

\section{Introduction}

In order to cope with the development of the world, the requirements in telecommunication will continuously increase. In order to allow a vast and rapid communication (i.e., to maximize the range of signals and the extent of the telephone and broadcast coverage), telecommunication and broadcast companies (namely, MTN, CAMTEL and ORANGE, CRTV with its transmitters, and other broadcast channels) proceeded with the installation of pieces of equipment of telecommunications in several rural and urban areas in Cameroon, on the mountains and the buildings. These installations require a reliable electric power supply, being without interruption.

Unfortunately, many areas are electrically isolated because they are not supplied by the interconnected electrical networks (according to [1] only about 14\% of the 13000 villages have access to electricity in Cameroon). In these particular areas, the installations of telecommunications witness a serious problem of electrical energy supply, despite the use of power generating units (generating units use petrol or gas oil for fuel, which from the environmental point of view contribute to pollution effect of greenhouse, and consequently accelerate the phenomenon of global warming). As for the urban areas, despite the presence of the interconnected electrical supply networks of AES-Sonel, telecommunication installations face serious problems of supply electric power in view of the important increase of telephone subscribers (close to 10 million subscribers according to [2]) and the recurrence of unballastings. Facing the difficulties of supply permanent and reliable energy, in spite of large investments (according to a source close to the 
general management, in ten years of activity in Cameroon, MTN affirms that it has invested, in Cameroon, more than 137249519,62 USD for telecommunication equipment), the companies of telecommunication know serious problems concerning the coverage of the network (according to [2], $20 \%$ of coverage against $95 \%$ of network coverage imposed by Agency of Regulation of Telecommunications).

According to [3], approximately $600 \mathrm{TWh}$ or $3 \%$ of the world's electrical energy is consumed by the ICTs (information and communication technologies) causing approximately $2 \%$ of the $\mathrm{CO}_{2}$ emissions in the whole world; $9 \%$ of this consumption of ICTs is caused by communication networks radio [4]. Within these radio communication networks, $10 \%$ of the energy is consumed by the users of terminals, while $90 \%$ is consumed by telecommunication base stations [5] Thus, the increase in the number of base stations by the telephone and audiovisual companies in Cameroon implies an increase in the global energy consumption that is increase in energy costs, which has also an impact on global warming especially in the Sahelian areas of Cameroon where we often encounter high temperatures. The rest of the paper is organized as follows: in Section 2, we present the bibliographical approach or the existing state of the art on the power consumption of base stations and the various existing approaches to be able to save energy in the base stations of telecommunication. The classification of base stations and the description of some base stations of Sahelian zone of Cameroon are presented, respectively, in Sections 3 and 4. The results on energy audits carried out in the three base stations and the proposal of a power consumption model are, respectively, presented in Sections 5 and 6. In addition, some solutions of realizable energy saving are detailed, respectively, in Sections 7 and 8. Finally, applicable technical solutions, in telecommunication base stations in the Sahelian zone in order to increase the energy efficiency, are presented in Section 9.

\section{State of the Art: Bibliographic Approaches of Energy Savings in Telecommunication Base Stations}

The growing interest towards new and reliable services in the field of mobile telecommunication has led to an increase in installation of number of base stations in the whole world. Besides, the traditional concept of the deployment of base stations ensures a continuous operation in order to constantly guarantee a quality of the service of network in any place. According to [6], these two reasons have contributed synergetically during the last decade to an important increase in energy consumption of base stations belonging to mobile telephone network operators.

According to [7], the distribution of power consumption averages of the various components of base stations is recapitulated in Figure 1.

It shows the power consumption by component in a base station; the largest energy consumer in base stations is the radiofrequency equipment (power amplifier plus the transceivers and cables), which consumes approximately

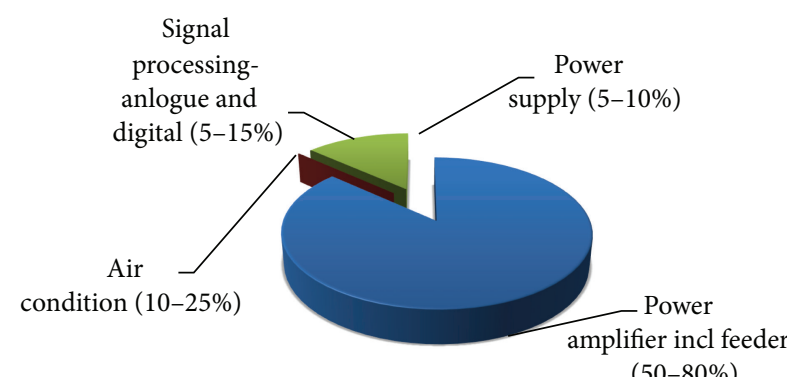

FIGURE 1: Energy consumption of the various components of the base stations [7].

$65 \%$ of the total energy. Among the other components of the base station, the important energy consumers are air conditioning (17.5\%), digital signal processor (10\%), and the AC/DC converter (7.5\%).

We notice that the radio operator equipment (the module of digital signal processing, the power amplifiers of transceivers, the radio frequencies, and connecting wires) and the systems of air cooling are the large-scale consumers of energy in telecommunication base stations. Emphasis must thus be laid on these components to reduce the total energy consumption of base stations.

In the zones of Sahel, the annual average temperatures are high; to reduce the energy consumption of base stations in these areas, an effort must be made on the control of the internal temperature of the room sheltering the equipment or on the system of air cooling.

To optimize energy consumption in a telecommunication base station, we answer three principal questions: optimization of energy consumption of BTS (base transceiver stations), energy optimization of the site sheltering the BTS (base transceiver stations), and the energy optimization of the network and radio frequency connection.

\subsection{Power Optimization Consumption of BTS (Base Tran-} sceiver Stations). Research is focused on several components of the BTS to improve their energy efficiency. Research is more focused on the amelioration of the linearization and energy efficiency of the power amplifier. The energy efficiency can be improved by using an especially designed power amplifier containing special materials for the transistors of the power amplifier, like materials of high frequency such as $\mathrm{Si}$, GaAs [9]. A numerical technique of predistortion can be used in the power amplifier to cancel the distortion of energy and so give a better linearity [10].

The power consumption of the digital signal processor can be reduced by using, for example, integrated circuits architectures like ASIC, FPGA, or DSP which are combined to obtain a better efficiency [11].

The AC/DC converter can be ameliorated by using converters that have a good efficiency in terms of energy being able to improve; thus, the total energy efficiency of the BTS, even in situations where the traffic load, is very bulky.

The power consumption caused by air conditioning can be reduced by lowering the operational temperature of base 
stations to the minimum or by using additional elements such as heat exchangers, membrane filters, and "smart" fans or heat modules [12].

2.2. Power Optimization of the Premises Accommodating the BTS. Energy savings in a base station can be obtained by putting into place the distributed architecture of a base station, where the radio frequency equipment is placed near the antenna in order to minimize losses in cables [13]. The possibilities to use renewable energies such as photovoltaic panels and wind energy on the sites of base stations are under study. By combining these two sources of renewable energies, one can reduce the potential of power consumption cost of a base station by $50 \%$ [14].

2.3. Optimize Power Consumption of the Network and Radio Frequency Connection. The potential of energy savings at the level of the connection is mostly found in the techniques of transmission by interface with air.

The level of contact considers the possible modes of sleep of certain components of the base station, when some of them can be switched off during certain times. In this case, the base station must provide a certain difference between the transmissions ordered by the traffic load in strong connection or in weak connection [15].

The energy efficiency in a base station obtained by the modes of sleep can be increased through the implementation of tedding techniques and flowering of cells. These techniques, used for the conception of base stations that have transitional states of sleep, consist of a progressive commutation of "switching off and on" a base station. It is shown that these transitional states are too short, which enable the base station to switch off and on for a short time which does not have a great significant reduction in the energy savings obtained through the approaches of sleep [16].

The system of $4 \mathrm{G}$ ( $4 \mathrm{th}$ generation of wireless networks) is envisaging the possibility of a dynamic allocation of the spectrum of frequencies as a function of the traffic load [17]. The cancellation of interferences in cellular networks by using the distributed antenna systems and algorithms, such as linear forcing to zero, the minimal error squared, and the cancellation of successive interferences, contributes also to the reduction of energy consumption [18].

At the level of the network, one of the most important approaches to reducing the consumption of energy is the dynamic management of network resources, which in fact enables the switching off of equipment of base stations at the time of weak traffic load. In such a scenario, neighboring base stations must ensure network coverage and take care of the network traffic of subscribers situated in the area where the base stations are not activated [15]. This can be combined with a dynamic selection of transmitter power, by tilting the antenna, by relaying multiskip, or by coordinating the transmission and reception in several points (multipoint) [19].

An important concept to reduce energy consumption of mobile telephone networks is presented in the context of the evaluation of energy efficiency, which includes several models that can ameliorate the energy efficiency on weak load traffic [18]. These models are subdivided into small sample models for short-term and large sample models for longterm. The small sample models for short-term are power models of which the cartography of RF power (radio frequency) brings out of the antenna radiated power, and the latter is assimilated to the total power supply of the site of the base station. The large sample models for long-term include the traffic models that describe the variation of the traffic load during a day and the models of deployment at small samples existing in geographically large areas. The energy efficiency can also be ameliorated without switching off certain equipment of the base station, using a technique called attenuation of cellular networks. This method is built as a problem of optimization at multiperiod enabling the attenuation frequency to switch off certain frequencies of the canals of the base station. The attenuation frequency can be combined with the service of attenuation, which stops certain services at high rate of data on the permitted frequencies during the periods when the traffic load demand is weak [20].

In the case of network architecture of heterogeneous mobile telephone, the network itself represents the potential of reducing energy consumption. In this type of network, the macrocells are completed with cells of weak transmission power such as micro-, Pico-, and femtocells [17]. The macrocells ensure permanent network coverage; meanwhile, the putting into service and out of service of small cells depend on the traffic load present. The possibility of applying techniques such as the zooming of cells, where the cell can adjust its size depending on the situation of the traffic load, is also explored in [21].

The potential of reduction of the energy consumption of networks is also found at the level of its planning and its functioning. One of the models proposed is the Traffic-Aware Network Planning cadre and Green Operation (TANGO) Framework, which seems to be an implementation of the future, being capable of increasing the energy efficiency of mobile telephone networks while conserving the quality of the service at a satisfactory level [22]. Besides, certain initiatives are based on the possibility of making energy savings through a cooperation between competing operators that offer the same services in the same area of coverage (generally in towns). The fact is that one of the operators can completely switch off its base stations during a weak traffic load, while the base stations of the second operator accept the subscribers from the two operators. According to the authors of [23], such an approach can offer reductions in energy consumption by $20 \%$. In [8], the authors propose several solutions that can ameliorate the energy efficiency of base stations of $4 \mathrm{G}$ (4th generation of wireless networks). These solutions can be observed from time, the frequency, and spatial domain, and the most promising solutions are hybrid solutions that combine the solutions in the different domains to adapt the energy consumption of the site of the base station to the conditions of the traffic load. In fact, the simultaneous use of most of the approaches mentioned will have a synergetic effect that leads completely to an energy efficiency of mobile telephone networks.

It turns out that base stations are greatest energy consumers in the mobile communication chain. This energy 


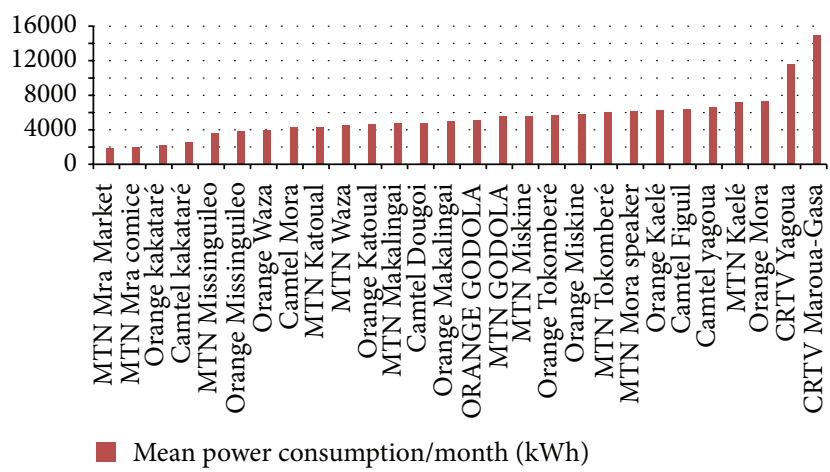

FIGURE 2: Energy consumption of some telecommunications base stations in the Sahel area of Cameroon.

consumption is better controlled in western countries than in sub-Saharan countries (where the average temperatures are very high); thus, we have to find how to control the power consumption of base stations situated in the Sahel area of Cameroon (the annual average temperatures are high) by proposing solutions of energy savings. The approaches of energy efficiency in base stations in general are recent and do not reveal the specific case of base stations situated in Sahel areas (where one witnesses average temperatures variations).

\section{Power Consumption and Classification of Base Stations in the Sahel Zone of Cameroon}

The visit to several sites accommodating base stations allowed to count base stations in terms of their energy consumption (see Figure 2).

It turns out that according to the classification of base stations defined in [24], one finds two types which include base stations of whose equipment is placed on the ground and indoors (encountered fields in town) and the base stations of distributed architecture and outdoors (encountered where there are buildings).

Besides these two types, there are also the relay stations of audiovisual companies such as CRTV. In sum, in the Sahel zone, there are three types of base stations:

(i) Traditional base stations indoors (the equipment is placed on the ground).

(ii) Base stations of distributed architecture and outdoors.

(iii) Base stations of audiovisual companies in which the specificity is the presence of several radio transceivers and TV (television).

It turns out from the above figure that the base stations of distributed architecture and outdoors (from MTN Maroua Market to Camtel kakataré) consume less power than the traditional base stations (from MTN Missinguileo to orange Mora). The latter in their turn consume less energy than the audiovisual stations (CRTV Maroua and CRTV Yagoua). Thus, there are three ranges of power consumption:

(i) Nonordinary base stations which have large power consumption (more than $10000 \mathrm{kWh} /$ month), it is
TABLE 1: Equipment of the TV room.

\begin{tabular}{|c|c|c|}
\hline Equipment & Power & $\begin{array}{l}\text { Other characteristics } \\
\text { and working hours }\end{array}$ \\
\hline TV emitter & $2,5 \mathrm{KW}$ & Working $24 \mathrm{~h} / 24$ \\
\hline $\begin{array}{l}\text { Air conditioning } \\
\text { system }\end{array}$ & $2900 \mathrm{~W}$ & $\begin{array}{c}\text { Working } 24 \mathrm{~h} / 24 \text { at } \\
20^{\circ} \mathrm{C}\end{array}$ \\
\hline Hot air extractor & $2850 \mathrm{~W}$ & Working $24 \mathrm{~h} / 24$ \\
\hline Seven lighting lamps & $36 \mathrm{~W} \times 7$ & Working $24 \mathrm{~h} / 24$ \\
\hline $\begin{array}{l}\text { Communication } \\
\text { equipment of the } \\
\text { national gendarmerie }\end{array}$ & $\begin{array}{l}\text { Power } 20 \mathrm{~W} \text {, } \\
\text { supply } 48 \mathrm{~V}\end{array}$ & Working $24 \mathrm{~h} / 24$ \\
\hline
\end{tabular}

the case of the station CRTV Maroua (has several transmitters of high power and air conditioning system of high power).

(ii) Traditional base stations (equipment placed on the ground in a premises) which have medium power consumption (consumption ranging from $3000 \mathrm{kWh} /$ month and $10000 \mathrm{kWh} / \mathrm{month}$ ), it is the case of the station MTN Missinguileo (indoor station using air conditioners).

(iii) Base stations of distributed architecture and outdoors which have small power consumption (consumption less than $3000 \mathrm{kWh} /$ month), it is the case of the station MTN Maroua Market (outdoor station and with distributed architecture).

Some energy audits were carried out on the sites of CRTV Maroua, MTN Missinguileo, and MTN Maroua Market.

\section{Characteristics of Base Stations of CRTV Maroua, MTN Missinguileo, and MTN Maroua Market}

4.1. CRTV Maroua Site. CRTV Maroua, like all other audiovisual companies, is endowed with several radio transceivers and television enabling the service in radio/television communication in Far North Region.

The equipment ensuring the transmission and the reception are accommodated in GASA neighborhood. They are distributed in three rooms (TV room, FM room, and RFI room). The electric power delivered by AES-Sonel on the site is about $160 \mathrm{kVa}$ with a power factor of 0.8 .

The transceivers (TX) of all rooms, and others equipment in this site, are represented in Supplementary Annexes 1 (In Supplementary Material available online at http://dx.doi.org/ $10.1155 / 2016 / 3161060$ ).

4.1.1. TV Room. The TV room is the one accommodating the TV emitter. The equipment found in this room is listed in Table 1.

The TV transceiver enables collecting television signals coming from National TV, amplifying, and supplying almost all the Far North Region. The hot air extractor enables emptying the room, at every moment when the temperature of the room is high and the air conditioning system is out of service. 
TABLE 2: Equipment of the FM room.

\begin{tabular}{lcl}
\hline Equipment & Power & Other characteristics and working hours \\
\hline 2 FM TX 10 KW (national program and local program) & $2 \times 22.5 \mathrm{KVA}$ & Working 24 h/24; frequencies of emission: \\
& & $98.10 \mathrm{MHz}$ for FM National and $94.80 \mathrm{MHz}$ for \\
Dummy load & $1 \mathrm{KVA}$ & Working $24 \mathrm{~h} / 24$ \\
PIE RACK & $1 \mathrm{KVA}$ & Working $24 \mathrm{~h} / 24$ \\
Measuring equipment & $1 \mathrm{KVA}$ & Working $24 \mathrm{~h} / 24$ \\
Dehydrator & $1,5 \mathrm{KVA}$ & Serial number: 35651 , Sumiden Opcom, Ltd, NP: \\
Two air conditioners & $2 \times 12 \mathrm{KVA}$ & 1604 , working $24 \mathrm{~h} / 24$ \\
Spare & $0,5 \mathrm{KVA}$ & Working $24 \mathrm{~h} / 24$, adjusted at $19^{\circ} \mathrm{C}$ \\
Transformer isolator & $80 \mathrm{KVA}$ & Working $24 \mathrm{~h} / 24$ \\
Voltage regulator & $75 \mathrm{KVA}$ & Working $24 \mathrm{~h} / 24$ \\
Two lighting lamps & $2 \times 36 \mathrm{~W}$ & AVR and PDB, work $24 \mathrm{~h} / 24$ \\
\hline
\end{tabular}

TABLE 3: Equipment of the RFI room.

\begin{tabular}{|c|c|c|}
\hline Equipment & Power & Other characteristics \\
\hline TX/RX RFI north Cameroon & $1 \mathrm{KW}(2 \times 500 \mathrm{~W})$ & FMTX Model T213SJ, DRX 3200, QPSK receiver \\
\hline TX/RX 900 GSM et 1800 GSM ORANGE Cameroon & $\operatorname{Max} 3600 \mathrm{~W} \times 2$ & Alcatel 02G 89450736652, ABIS1TXRX ABIS 1TXRX \\
\hline Energy bay ELTEC (charger of batteries made rectifiers AC/DC) & & Output voltage $53,4 \mathrm{~V}$ \\
\hline 16 batteries & $12 \mathrm{~V}-160 \mathrm{Ah}$ & $\begin{array}{l}\text { Monolite } 12 \mathrm{FFT} 160,12 \text { scpe } \mathrm{CF} 150 \\
12 \mathrm{~V} 160 \mathrm{Ah} / 10 \mathrm{hr} \text { to } 1,80 \mathrm{~V} / \mathrm{cell} \text { at } 20^{\circ} \mathrm{C} \\
12 \mathrm{~V} 160 \mathrm{Ah} / 8 \mathrm{hr} \text { to } 1,75 \mathrm{~V} / \mathrm{cell} \text { at } 77^{\circ} \mathrm{C} \\
\text { Float voltage } 13,62 \mathrm{~V} \text { at } 20^{\circ} \mathrm{C} / 13,56 \mathrm{~V} \text { at } 77^{\circ} \mathrm{C}\end{array}$ \\
\hline Five security lamps & $11 \mathrm{~W} \times 5$ & $220 \mathrm{~V}-50 \mathrm{~Hz}$ \\
\hline Three lighting lamps & $36 \mathrm{~W} \times 3$ & $240 \mathrm{~V}-50 \mathrm{~Hz}$, work at $24 \mathrm{~h} / 24$ \\
\hline Two split air conditioning systems & $3800 \mathrm{~W}$ & $\begin{array}{l}\text { Maintain the internal temperature of the room } \\
\text { averagely at } 24^{\circ} \mathrm{C} \text {. Work } 24 \mathrm{~h} / 24 \text { and adjusted at } 20^{\circ} \mathrm{C} \text {. }\end{array}$ \\
\hline
\end{tabular}

4.1.2. FM Room. The FM room is the one accommodating the regional and national FM transceivers.

The equipment located in this room is listed in Table 2.

The two national and regional transceivers enable supplying the entire region by radio waves of CRTV Maroua and the national station broadcasted from Yaounde; they also have a range of $200 \mathrm{Km}$.

The two air conditioning systems enable cooling the FM room, because

(i) the FM transceivers in their internal working procedure produce heat;

(ii) the room in which those pieces of equipment are accommodated is built out of concrete (and thus absorbs the heat of the day and rejects it into the room) and has only one opening (door);

(iii) the external temperature in Sahel zone is high.

The dehydrator dehydrates the air of the room in order to maintain the hygrometry around 50\%; the values of temperatures are given by the temperature sensor.

The frequency selector switch enables conditioning the different frequencies in order to move towards the antennas; it also enables equally switching from regional FM to national FM.
4.1.3. RFI Room. The equipment found in this room is listed in Table 3.

Apart from the equipment of power consumption, found in the three rooms (TV, FM, and RFI), there are a TV set $(77 \mathrm{~W}, 260 \mathrm{~V}$ ) functioning on average $18 \mathrm{~h} / 24$ (from 6:00 am to 12:00 midnight), 4 lighting lamps in the corridor of $36 \mathrm{~W}$ each (working time: whole day), and 8 external lighting lamps of $36 \mathrm{~W}$ each (working time: whole day).

4.2. Missinguileo Site. The base station of Missinguileo neighborhood is a station of emission and reception. It is consisted of the radio antennas (the "drums" or point to point antenna), antennas of cover (antenna with small range in the form of "stick"), and also the antennas WIMAX emission (used for the internet network). This station is located on a mountain of approximately 230 meters high. The pylon in question has a height of $55 \mathrm{~m}$. It is an indoor station (in an iron container). The temperature in the room containing the machines is maintained at $21^{\circ} \mathrm{C}$ by the cooling systems. Equipment characteristics' are listed in Table 4 and pictures of these equipment are represented in Supplementary Annexes 2.

4.3. Site of Maroua Market Site. The site sheltering the base station of MTN Maroua Market is set on a building of three 
TABLE 4: Equipment of MTN Missinguileo site.

\begin{tabular}{|c|c|c|}
\hline Equipment & Electrical characteristics & Other characteristics \\
\hline AES-Sonel supply & $\begin{array}{l}\text { Amperage } 10-30 \mathrm{~A} \text {, voltage } \\
220 \mathrm{~V} / 400 \mathrm{~V}, \cos \varphi=0,8 \\
\text { Power supplied: } 15 \mathrm{kVa} \\
\end{array}$ & Couple $\mathrm{C}=2,5 \mathrm{wh} / \mathrm{tr}$ \\
\hline $\begin{array}{l}2 \text { TX/RX } 900 \text { GSM (DRU) et TX/RX } 1800 \\
\text { GSM (DRU) }\end{array}$ & $\begin{array}{l}\text { Max } 3600 \mathrm{~W} \times 3 \\
\text { Supply } 48 \mathrm{~V} \text { DC }\end{array}$ & ERICSON 02G 89450736652; work at $24 \mathrm{~h} / 24$ \\
\hline $\begin{array}{l}\text { Energy bay Emerson Network Power } \\
\text { (charger of batteries made of rectifiers } \\
\text { AC/DC) }\end{array}$ & $\begin{array}{l}\text { Redresseurs } 220 \mathrm{~V}-24 \mathrm{~V} \\
\text { Puissance minimale } 10 \mathrm{KW}\end{array}$ & Works $24 \mathrm{~h} / 24$ \\
\hline Eight accumulator batteries & $\begin{array}{l}\text { Power sonic PG-6V 220B; } 6 \text { volts } \\
226 \text { A.H }\end{array}$ & $6 \mathrm{~V}-200 \mathrm{~A}$; autonomy $8 \mathrm{~h}$; temperature $27^{\circ} \mathrm{C}$. \\
\hline Power system ERICSON & $\begin{array}{l}\text { DC output: } 24 \mathrm{~V} \text { ou } 48 \mathrm{~V} \\
\text { DC/200A/6,4 KW }\end{array}$ & Works $24 \mathrm{~h} / 24$ \\
\hline Standby generating set & $\begin{array}{l}\text { Apparent power } 20 \mathrm{KVA} \text {; power } \\
\text { factor } 0.8 \text {; output } 16 \mathrm{KW}\end{array}$ & Works automatically in case of AES-Sonel power cut \\
\hline Two air conditioning systems & $\begin{array}{l}\text { Cooling input power: } 2410 \mathrm{~W} \\
\text { Rated voltage: } 220 \mathrm{~V}-230 \mathrm{~V}\end{array}$ & $\begin{array}{l}\text { Only one system works and is adjusted at } 23^{\circ} \mathrm{C}, 24 \mathrm{~h} / 24 \text {. } \\
\text { The second is under failure }\end{array}$ \\
\hline Five buoying lamps of red coulor & $11 \mathrm{~W} \times 2$ & $220 \mathrm{~V}-50 \mathrm{~Hz}$, work from 6:00 pm to 6:00 am \\
\hline Four lighting lamps & $36 \mathrm{~W} \times 4$ & $240 \mathrm{~V}-50 \mathrm{~Hz}$, work at $24 \mathrm{~h} / 24$ \\
\hline $\begin{array}{l}\text { One radio equipment } \\
\text { Airmux } 200\end{array}$ & $\begin{array}{l}\text { Supply } 48 \text { V DC } \\
3 \mathrm{~W}\end{array}$ & $\begin{array}{l}\text { Serial LIU STM-1/STS-3; E1/T1 way side A B. } \\
\text { P1-Direction KATOUAL CH1 } \\
\text { P2-Direction KATOUAL CHP }\end{array}$ \\
\hline WIMAX equipment & $\begin{array}{l}\text { Supply } 48 \text { V DC } \\
14 \mathrm{~W}\end{array}$ & $\begin{array}{l}\text { Supplies six directorates in internet network: } \\
\text { (i) Lycée Kaelé (Centre multimédia) } \\
\text { (ii) Camair-co } \\
\text { (iii) Régionale AMCHIDI } \\
\text { (iv) Direction Sonel Maroua } \\
\text { (v) CDC Bomtock } \\
\text { (vi) Afriland First Bank Kousseri }\end{array}$ \\
\hline $\begin{array}{l}\text { Multiplexer OSN } 2500 \\
\text { Digital multiplexer } 2 / 34\end{array}$ & $\begin{array}{l}400 \mathrm{~W} \\
15 \mathrm{~W}\end{array}$ & $\begin{array}{l}\text { Of trademark HUAWEI, work } 24 \mathrm{~h} / 24 \\
\text { SMU } 16 \times 2 \text {; MMU } 34+2\end{array}$ \\
\hline
\end{tabular}

levels. The BTS system (excluding the aerials) is set on the 2nd level and the aerials are set on the roof of the 3 rd level. The equipment is outdoors or are set on one shelter (shelter open to the free air). This site is located near the market of Maroua.

The three BTS enable covering in network, all the population of the market, and the neighboring area. In this zone of coverage, the traffic is dense considering the density of the population and the flow of people in the market. This type of site does not require air conditioning system (air conditioner) as in the indoor sites.

Equipment characteristics are listed in Table 5 and images of these pieces of equipment are represented in Supplementary Annexes 2 showing equipment set on the shelter and the aerials set on the roof.

\section{Energy Audits in Base Stations}

\subsection{Site of CRTV Maroua}

\subsubsection{Remarks and Investigations Made on the Site of CRTV Maroua}

(i) Lighting is insufficient in this day (small openings or windows and they are less wider). (ii) The buildings are constructed in concrete cement and the roof is paved out of concrete.

(iii) The air conditioners of the FM room equally aircondition the TV room and sometimes the RFI room since the air conditioners of these last two rooms are regularly broken down.

(iv) The lamps are lit constantly. The lamps located outside and in the corridors of the buildings are sometimes not switched off during the day, which also increase the power consumption of the site.

(v) The site has only one source of energy, and the power generating unit used as standby is out of service for more than five years.

5.1.2. The Power Consumption of the CRTV Site from December 10 to July 12. By observing Figure 3, from December 10 to July 12 , the energy consumption of the CRTV site is varied. During the months of December 10, January 11, February 11, August 11, September 11, November 11, January 12, and February 12, the energy consumption is lower than the average consumption (14750 kWh). This low consumption compared to the others is due, on the one hand for January, February, and November, to the low temperature (the less the temperature is, the less 
TABLE 5: Equipment of the MTN Maroua Market site.

\begin{tabular}{|c|c|c|}
\hline Equipment & Electrical characteristics & Other characteristics and working hours \\
\hline AES-Sonel supply & $\begin{array}{l}\text { Amperage } 10-30 \mathrm{~A} \text {, voltage } \\
220 \mathrm{~V} / 400 \mathrm{~V}, \cos \varphi=0.8 \\
\text { Power supplied: } 15 \mathrm{kVa}\end{array}$ & Couple $\mathrm{C}=2,5 \mathrm{wh} / \mathrm{tr}$ \\
\hline $\begin{array}{l}2 \text { TX/RX } 900 \text { GSM (DRU) et TX/RX } 1800 \\
\text { GSM (DRU) }\end{array}$ & $\begin{array}{l}\text { Max } 3600 \mathrm{~W} \times 3 \\
\text { Supply } 48 \mathrm{DC}\end{array}$ & Ericsson $02 \mathrm{G} 89450736652$ work at $24 \mathrm{~h} / 24$ \\
\hline $\begin{array}{l}\text { Two energy bays Ericsson (charger of } \\
\text { batteries made of AC/DC rectifier) }\end{array}$ & $\begin{array}{l}\text { Rectifier } 220 \mathrm{~V}-24 \mathrm{~V} \\
\text { Power } 10 \mathrm{KW}\end{array}$ & $\begin{array}{l}\text { Each bay possesses an evacuation system of the internal } \\
\text { heat to the casket, enabling keeping a fairly low } \\
\text { temperature }\end{array}$ \\
\hline 16 accumulator batteries & $\begin{array}{l}\text { Power sonic PG-6V 220B; } 6 \text { volts } \\
226 \text { A.H }\end{array}$ & $6 \mathrm{~V}-200 \mathrm{~A}$; autonomy $7.8 \mathrm{~h}$; temperature $27^{\circ} \mathrm{C}$. \\
\hline Power system Ericsson & $\begin{array}{l}\text { DC output: } 24 \mathrm{~V} \text { or } 48 \mathrm{~V} \\
\text { DC/200 A/ } 6,4 \mathrm{KW}\end{array}$ & Works $24 \mathrm{~h} / 24$ \\
\hline Two lighting lamps & $36 \mathrm{~W} \times 2$ & $240 \mathrm{~V}-50 \mathrm{~Hz}$, work from 6:00 pm to $6: 00 \mathrm{am}$ \\
\hline $\begin{array}{l}\text { Two equipment radios } \\
\text { Winlink } 2000\end{array}$ & $\begin{array}{l}\text { Supply } 48 \mathrm{~V} \mathrm{DC} \\
2 \times 2,4 \mathrm{~W}\end{array}$ & $\begin{array}{l}\text { Serial LIU STM-1/STS-3; E1/T1 way side A B. } \\
\text { P1-Direction Maroua Dougoi CH1 } \\
\text { P2-Direction Maroua Dougoi CHP } \\
\text { P3-Direction Maroua Comice CH2 } \\
\text { P4-Direction Maroua Comice CHP } \\
\text { Work at } 24 \mathrm{~h} / 24\end{array}$ \\
\hline
\end{tabular}

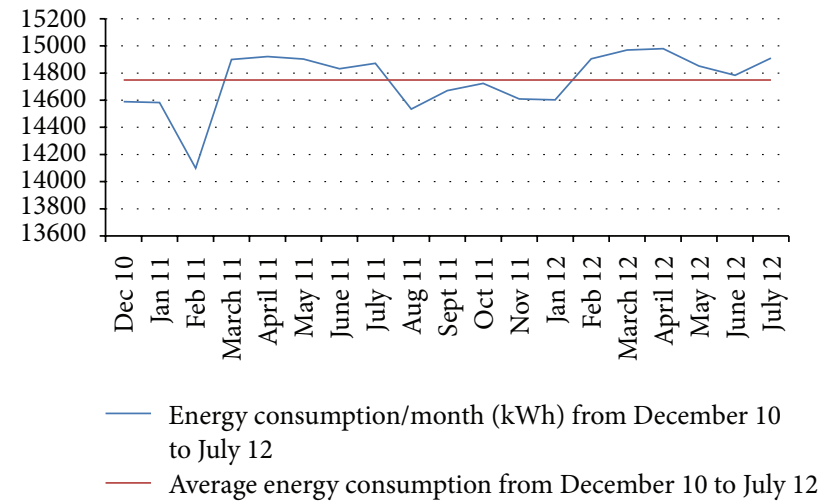

Figure 3: Monthly energy consumption curve, CRTV site from December 10 to July 12 .

the air conditioners function); On the other hand, the drops of consumption in energy for August and September are due to the multiple power cuts because of heavy rains. As for the consumption higher than the average, it is due to the high temperatures during the months concerned.

Thus it arises from the graph that low consumption is recorded during the rainy and cold seasons, and the highest consumption takes place during the dry season (March, April, and May).

\subsubsection{Estimation of Costs Related to the Monthly and Annual} Energy Consumption. As represented in Figure 4, the cost related to the energy consumption of the CRTV site Maroua varies; the months when consumption in energy is high also have a high cost of energy. For the year 2011, the cumulative of expenditure on the power consumption is approximately 27 908,409 USD.

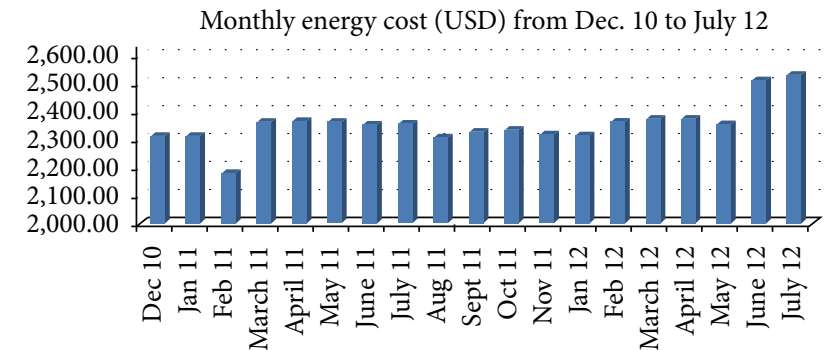

FIGURE 4: Estimation costs curve for monthly energy consumption, CRTV site from December 10 to July 12.

We notice that in 2012, although consumption of energy in March (14969 kWh) and April (14981 kWh) exceeds the consumption of the months of June $(14783 \mathrm{kWh})$ and July $(14910 \mathrm{kWh})$, the energy costs related to the months of June (2 511,077 USD) and July (2 532,508 USD) are higher than the costs of energy related to the months of March (2374,593 USD) and April (2376,855 USD); this is explained by the new grid of tariffing of electricity of AES-Sonel whose price of the kWh rise from 0,157896 USD to 0,169910 USD.

\subsection{Site of MTN Missinguileo}

\subsubsection{Remarks and Investigations Carried Out on the Site of MTN Missinguileo}

(i) The site of MTN Missinguileo being located at a high altitude, that is why, on this site, the temperature being relatively low;

(ii) The container, in which the equipment is placed, being made out of iron on a surface of approximately $50 \mathrm{~m}^{2}$ and a $3,5 \mathrm{~m}$ height; 


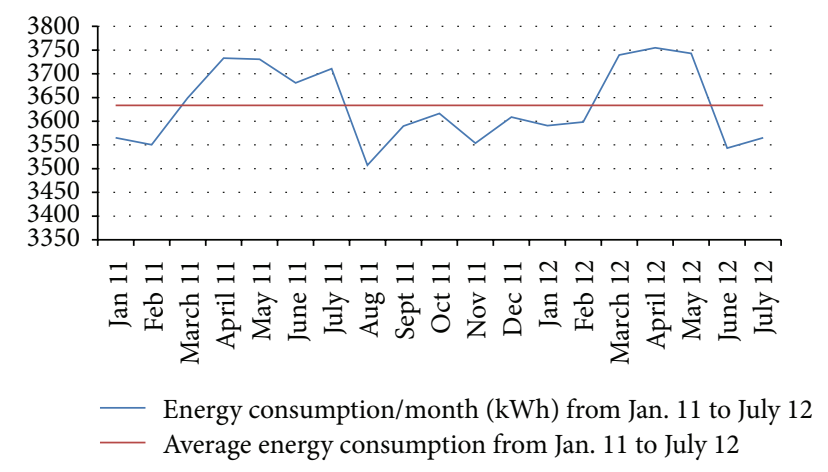

FIGURE 5: Monthly energy consumption curve, Missinguileo site from January 11 to July 12.

(iii) Lack of openings along the wall for the exchange of air with the outside;

(iv) External lighting being lit on $24 \mathrm{~h} / 24$;

(v) Only one air conditioner ensuring the air conditioning system;

(vi) The source of emergency power supply being a power generating unit, consuming on average 2000 liters of gas oil per year.

5.2.2. Existing Energy Consumption MTN Missinguileo 2011. By observing Figure 5, it turns out that the mean of the monthly consumption, from January 11 to July 12 , is estimated at $3633 \mathrm{kWh}$.

We notice that throughout the year 2011, the greatest energy consumption is recorded at the time of April (3733 kWh) and of May (3730 kWh) which belong to, according to the seasons of the Sahel zone, the hottest months. Once again, we say that the rise of consumption in energy is related to the rise of the temperatures on the sites of the base stations. August records lowest consumption in energy (3507 kWh); this low consumption is once more due to the inopportune and intense power cuts in the town of Maroua during the rainy season; this month is equally one of the least hot months of the year in the Sahel region of Cameroon. The annual energy consumption is approximately $43496 \mathrm{MWh}$. As for the year 2012, we notice that the hottest months of the year, March (3740 kWh), April (3755 kWh), and May (3743 kWh), are the most energy "consumers."

As for monthly load factors of the site, they are not set out for insufficient data; the maximum demands in power are difficult to establish since the only material enabling the records is the AES-Sonel meter who only indicates instantaneously the total energy consumed on the site.

5.2.3. Estimation of Costs Related to the Monthly and Annual Energy Consumption. As represented in Figure 6, the variation of energy costs related to the consumption of electrical energy from AES-Sonel origin on the MTN Missinguileo site. The most significant costs are those of the months of August11 (lowest energy cost because of low energy consumption) and June 12 and July12 (highest energy costs because of the new

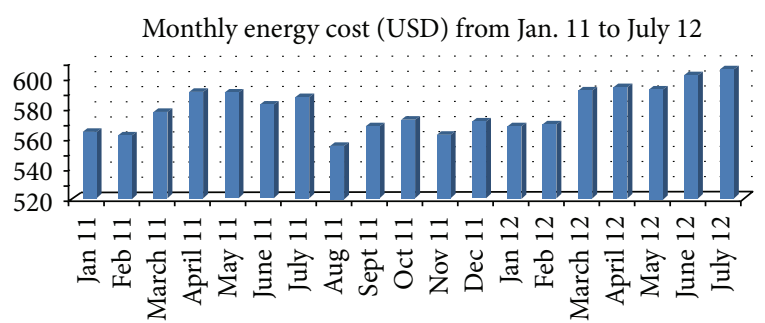

FIGURE 6: Estimation costs curve for monthly energy consumption, Missinguileo site from January 11 to July 12 .

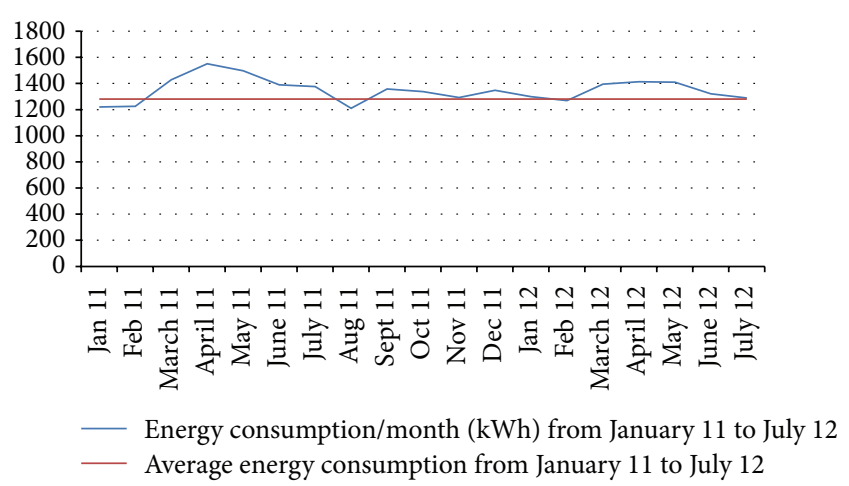

Figure 7: Monthly energy consumption curve, MTN Maroua Market site from January 11 to July 12.

grid of tariffing of electricity). The cumulative cost related to the energy consumption from source AES-Sonel for the year 2011 is estimated at 6879,99 USD.

The cost of one liter gas oil is 0,8918 USD (source: $\mathrm{CSPH}$; Calculations SIE-Cameroun); thus, the annual cost 2011 related to the gas oil is $2000 \mathrm{~L} \times 0,8918 \mathrm{USD}=$ 1783,6 USD/year.

The total cost for expenditure 2011 on the energy consumption is thus 8663,59 USD.

\subsection{Site of MTN Maroua Market}

\subsubsection{Remarks and Investigations Carried Out on the Site of MTN Maroua Market}

(i) The site of MTN Maroua Market is set on the roof of a building.

(ii) Outdoor station does not require air conditioning.

(iii) The lamps are lit on $24 \mathrm{~h} / 24$.

5.3.2. Existing Power Consumption MTN Maroua Market from January 11 to July 12. From Figure 7, it appears that the average of the monthly consumption in energy from January 11 to July 12 turns around $1281 \mathrm{kWh}$. We notice that, for the year 2011, the energy consumption is higher in month of April (1551 kWh) and lower in August (1221 kWh). For the same reasons explained above, in the case of the base station of Missinguileo, during the hottest months, there is more consumption in energy. 


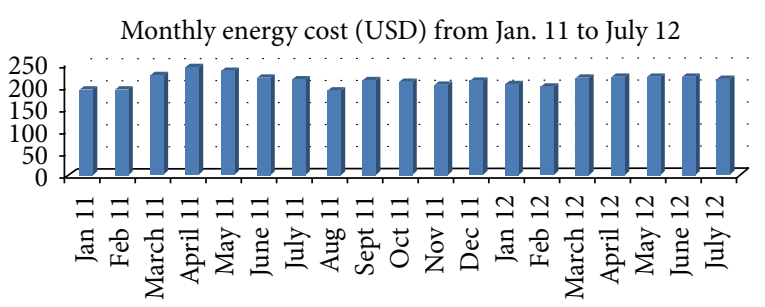

FIGURE 8: Estimation costs curve for monthly energy consumption, MTN Maroua Market site from January 11 to July 12.

During the year 2012, we note that in February the energy consumption $(1268 \mathrm{kWh})$ remains lowest of the 07 recorded first. High consumption is known, once more during the hot periods of the year, which are March (1395 kWh), April (1413 kWh), and May (1409 kWh).

As for the monthly load factors of the site, they are not set out for insufficient data; the maximum demands for power are difficult to establish since the only material allowing the records remains the AES-Sonel meter, only indicating instantaneously the energy consumption of the site.

5.3.3. Estimation of Costs Related to the Monthly and Annual Energy Consumption. The variation of electrical energy costs from AES-Sonel on the site of MTN Maroua Market is represented in Figure 8 . These costs vary around a monthly average of 214,88 USD. The cumulative cost of the year 2011 related to the energy consumption is estimated at 2578,713 USD.

\section{Proposal of a Model of Energy Consumption of Base Stations}

Faruk et al. [25] propose the following model of energy consumption for a BTS (1): the total power of a BTS and total energy consumed are $P_{\mathrm{BTS}}$ and $E_{\mathrm{BTS}}$ :

$$
\begin{aligned}
& P_{\mathrm{BTS}}=P_{\mathrm{DP}}+P_{\mathrm{Ampl}}+P_{\mathrm{RU}}+P_{\mathrm{cov}}+\sum_{i}^{m} P_{\mathrm{AC}_{i}}+\sum_{j}^{m} P_{\mathrm{LB}_{j}}, \\
& E_{\mathrm{BTS}}=P_{\mathrm{BTS}} \cdot t .
\end{aligned}
$$

$P_{\mathrm{DP}}, P_{\mathrm{Ampl}}, P_{\mathrm{RU}}, P_{\mathrm{cov}}, P_{\mathrm{AC}_{i}}$, and $P_{\mathrm{LB}_{j}}$, respectively, are power of digital signal processing, power of amplifier, power of radio unit, power of $\mathrm{AC} / \mathrm{DC}$ converter, power of air conditioner $i$, and power of lamp $j$, and $t$ is the operating time.

To have an expression for the total energy consumption of a telecommunication base station (MTN, ORANGE, CAMTEL, and CRTV) in the Sahel zone of Cameroon, we considered the following:

(i) The energy consumption of the various BTS (BTS GSM900, BTS GSM1800,...).

(ii) The energy consumption of technologies of transmission for internet (WIMAX,...). and/or radio transmission at long distances point to point such as the Airmux 200 and IRT 2000.

(iii) The energy consumption of the air conditioners (if possible). (iv) The energy consumption of the lighting lamps.

(v) Losses of energies caused by the cables connecting the equipment of transmission and the antennas.

The energy consumption is defined as the product of the power supplied and the working time. It is given as follows:

$$
\begin{aligned}
E_{\mathrm{BTS}}= & P_{\mathrm{BTS}} \cdot t \\
= & \sum_{i=1}^{n} \sum_{j=1}^{n} P_{\mathrm{bts}_{i}} \cdot t_{j} \\
& +\sum_{i=1}^{m} \sum_{j=1}^{m} P_{\text {another trans equip }}(\text { WIMAWX }, . . .)_{j} \cdot t_{j} \\
& +\sum_{i=1}^{k} \sum_{j=1}^{k} P_{\text {multipl equip }_{i}} \cdot t_{j}+\sum_{i=1}^{l} \sum_{j=1}^{l} P_{\text {clim }_{i}} \cdot t_{j} \\
& +\sum_{i=1}^{g} \sum_{j=1}^{g} P_{\text {lamp }_{i}} \cdot t_{j}+\sum_{i=1}^{f} \sum_{j=1}^{f} P_{{\text {losses in } \text { cables }_{i}} \cdot t_{j} \cdot}
\end{aligned}
$$

With $P_{\text {bts }_{i}}, P_{\text {another trans equip }}\left(\right.$ WIMAWX,...) $_{1}, P_{\text {multipl equip }_{i}}, P_{\text {clim }_{i}}$, $P_{\text {lamp }_{i}}, P_{\text {losses in cables }} i$, respectively, being power of each equipment bts $s_{i}$ of transmission, power of other transmission equipment such as the WIMAX, Airmux 200, IRT 2000, and VSAT (very small aperture terminal), power of the equipment of the different multiplexers and others as well, power of the air conditioner $i$, power of lamp $j$, and power lost in the cable $i$ and $t$ is the operating time.

$E_{\mathrm{BTS}}$ represents the total energy consumption of the site accommodating the base station.

Thus, the meters of energy found on the different sites of the base stations record at constantly cumulated $E_{\mathrm{BTS}}$.

\section{Energy Saving Realized on the Sites of the Base Stations after Recommendations of Solutions in Energy Saving}

The solutions for energy savings were proposed in the three base stations. They are based firstly on the lighting and air conditioning system.

7.1. Solutions of Energy Saving on the Site of CRTV Maroua. We have proposed to increase the range of air conditioning of the air conditioners of the various rooms and to reduce the operating time of several lighting lamps (see Table 6).

(i) Increase of Range of Air Conditioning. The range of air conditioning of the FM and RFI rooms is increased by $2^{\circ} \mathrm{C}$ and $3^{\circ} \mathrm{C}$ in the night; thus, the air conditioners of the FM rooms are regulated to $21^{\circ} \mathrm{C}$ instead of $19^{\circ} \mathrm{C}$ in the day (8:00 am to $10: 00 \mathrm{pm})$ and $22^{\circ} \mathrm{C}$ in the night (10:00 pm to $\left.8: 00 \mathrm{am}\right)$. In the same way, the air conditioners of the RFI are regulated to $22^{\circ} \mathrm{C}$ instead of $20^{\circ} \mathrm{C}$ in the day $(8: 00$ am to $10: 00 \mathrm{pm})$ and $23^{\circ} \mathrm{C}$ in the night (10.00 pm to 8:00 am). This work was carried out from the 5th to 7 th June 2012. 
TABLE 6: Proposal of energy savings on the lighting aspect and air conditioning of the CRTV Maroua site.

\begin{tabular}{ll}
\hline Period & Characteristics of the site \\
\hline 8:00 am-6:00 pm & Widening of the climatic range by $2^{\circ} \mathrm{C}$ of the FM and RFI rooms, the lighting lamps are switched off \\
6:00 am-10:00 pm & Widening of the climatic range by $2^{\circ} \mathrm{C}$ of the FM and RFI rooms, the lighting lamps are switched on \\
10:00 pm-6:00 am & Widening of the climatic range by $3^{\circ} \mathrm{C}$ of the FM and RFI rooms, the lighting lamps are switched on \\
6:00 am-8:00 am & Widening of the climatic range by $3^{\circ} \mathrm{C}$ of the FM and RFI rooms, the lighting lamps are switched off \\
\hline
\end{tabular}

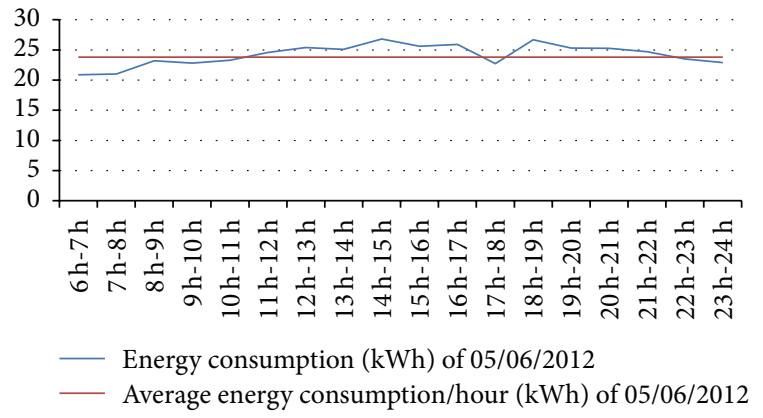

FIGURE 9: Hourly energy consumption curve of 05/06/2012.

(ii) Reduction of Operating Time of the Lamps. We have seen that the lighting lamps are lit only at the night that means from 6:00 pm to 6:00 am, and the records were carried out from 5th to 7th June 2012.

We have in total 23 lamps, of $36 \mathrm{~W}$ each, which light the site.

The periods in Table 6 are considered for energy consumption.

7.2. Application of Energy Savings Proposed. To evaluate the changes on the level of the energy consumption and the temperatures in the various rooms of the station, we followed the layout of power consumption time and the recorded temperatures time of the day of the $05 / 06 / 2012$. On that day, all the air conditioners are under operation as at the date of the $27 / 05 / 2012$, except for change on the climatic conditions and the lighting as indicated in the table of proposal for an energy savings (see Figures 9 and 10). The curves of variation of the energy consumption of the site of CRTV in the date of 05/06/2012 (see Figure 9) show an increasing time power consumption in the morning and decreasing in the evening. The time average of power consumption is $23,7955 \mathrm{kWh}$ lower than that recorded in the date of 27/05/2012 (28,60 kWh).

7.3. Energy Savings and Saving Costs Realized. To establish the difference between the energy consumption of the 27/05/2012, where the proposals for an energy saving (lighting and system of air conditioning) are not applied, and the energy saving from 5 th to 7 th June 2012, when the proposals of energy saving (lighting and system of air conditioning) are applied, we recapitulated the energy consumption of these days in Table 7 and Figure 11.

We notice that the power consumption, at various periods considered of the 27/05/2012 are higher than those of the

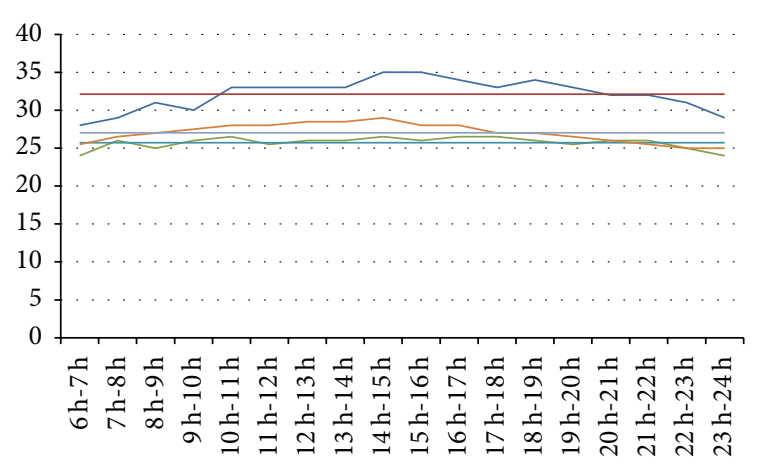

Temperature of TV room
- Average temperature of TV room
- Temperature of FM room
- Average temperature of FM room
- Temperature of RFI room
- Average temperature of RFI room

FIGURE 10: Hourly temperature curve of 05/06/2012.

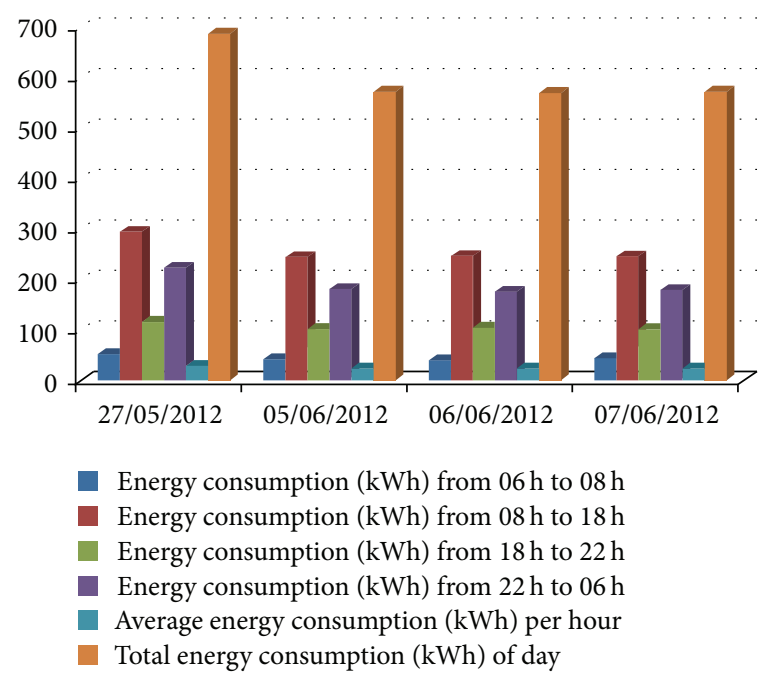

FIGURE 11: Comparison between energy consumption of the site, case of a day not applying the proposals of energy savings (27/05/2012), case of a day for which the air conditioner was under failure, and case of days applying the proposals of energy savings ( 05 , 06, and 07 June 2012).

days of 5th, 6th, and 7th June 2012. The daily power consumption average from 5 th to 7 th June 2012 is approximately $570 \mathrm{kWh}$ below $687 \mathrm{kWh}$ (that of the 27/05/2012) that is to say a realizable energy saving of $117 \mathrm{kWh}$ /day or $17 \%$ energy savings. By projecting measurements of energy saving over 
TABLE 7: Recapitulative of energy consumption of the 27/05/2012 and of from the 5th to 7th June 2012.

\begin{tabular}{|c|c|c|c|c|c|c|c|}
\hline Dates & $\begin{array}{c}\text { Energy } \\
\text { consumption } \\
\text { (kWh) of the } \\
\text { site 6:00 } \\
\text { am-8:00 am }\end{array}$ & $\begin{array}{c}\text { Energy } \\
\text { consumption } \\
\text { (kWh) of the } \\
\text { site } 8: 00 \\
\text { am-6:00 pm }\end{array}$ & $\begin{array}{c}\text { Energy } \\
\text { consumption } \\
\text { (kWh) of the } \\
\text { site 6:00 } \\
\text { pm-10:00 pm }\end{array}$ & $\begin{array}{c}\text { Energy } \\
\text { consumption } \\
\text { (kWh) of the } \\
\text { site 10:00 } \\
\text { pm-6:00 am }\end{array}$ & $\begin{array}{c}\text { Mean energy } \\
\text { consumption } \\
\text { (kWh) per } \\
\text { hour }\end{array}$ & $\begin{array}{c}\text { Total energy } \\
\text { consumption } \\
\text { (kWh) of the } \\
\text { day }\end{array}$ & $\begin{array}{l}\text { Energy } \\
\text { savings } \\
\text { realized } \% \text { to } \\
\text { the reference } \\
(27 / 05 / 2012)\end{array}$ \\
\hline $27 / 05 / 2012$ & 52.28 & 295 & 116 & 223.64 & 28.625 & 687 & - \\
\hline 05/06/2012 & 41.872 & 245,42 & 102 & 181.8 & 23.7955 & 571.092 & $\begin{array}{c}116 \mathrm{kWh} \\
\text { which is } \\
16.88 \%\end{array}$ \\
\hline 06/06/2012 & 40.569 & 247,78 & 104.23 & 176.92 & 23.7291 & 569.499 & $\begin{array}{c}118 \mathrm{kWh} \\
\text { which is } \\
17.17 \%\end{array}$ \\
\hline 07/06/2012 & 44.532 & 246.34 & 101.45 & 179.63 & 23.8313 & 571.952 & $\begin{array}{c}115 \mathrm{kWh} \\
\text { which is } \\
16.73 \%\end{array}$ \\
\hline
\end{tabular}

TABLE 8: Proposals of energy savings on the lighting and air conditioning aspects of MTN sites.

\begin{tabular}{lcc}
\hline Period & Characteristics of the site of MTN Missinguileo & Characteristics of the site of MTN Maroua Market \\
\hline 6:00 am-6:00 pm & No widening of the range of air conditioning, lamps & Lamps switched off \\
switched off & No widening of the range of air conditioning, external \\
lamps switched on & Lamps switched on \\
\hline
\end{tabular}

one month or a year, one will have approximately energy saving $3510 \mathrm{kWh} /$ month or $42120 \mathrm{kWh} /$ year; In terms of cost, the realizable energy savings are $595,94 \mathrm{USD} /$ month or 7151,34 USD/year. This realizable energy saving can supply an indoor base station like that of MTN Missinguileo (whose average consumption is $114 \mathrm{kWh} /$ day) or two outdoor base stations (absence of air conditioner) such as the site of MTN Maroua Market (of which the mean consumption is $54 \mathrm{kWh} /$ day).

\section{Solutions of Energy Savings on the Sites of Missinguileo and Maroua Market}

On the MTN sites of studied, we have proposed the reduction of the operating time of lighting lamps. Theses lamps can thus work from 6:00 pm to 6:00 am instead of allowing them to work throughout the day. As for the air conditioning system of the site of MTN Missinguileo, we have equally proposed an increase of the range of air conditioning at certain times of the day. Table 8 details proposals of energy savings on the lighting systems and air conditioning aspects of MTN sites.

By applying the proposals for an energy saving presented above on the sites of MTN Maroua Market et MTN Missinguileo, we plotted the curves of follow-up of the power consumption during three different days (from 16th to 18th July 2012).

8.1. Application of the Proposals of Energy Savings on the Missinguileo Site. Table 9 and Figure 12 recapitulate the power consumption of the MTN Missinguileo site from 16th to 18th July 2012, and the consumption of the $06 / 07 / 2012$ being used as comparison with other consumption.
By comparing the energy consumption at the time of 16 th, 17th, and 18th July 2012 to those of 6th July 2012, we notice that the energy consumption (consumption from 6:00 am to 6:00 pm, 6:00 pm-6:00 am, and the total daily consumption) of the 6th July 2012 is higher than those of the 16th, 17th, and 18 th July 2012. The daily power consumption average from 16th to 18th July is approximately $93 \mathrm{kWh}$ lower than $123 \mathrm{kWh}$ (that of the 6th July 2012), which is $30 \mathrm{kWh} /$ day, or $24.40 \%$ of realizable energy savings per day, or $900 \mathrm{kWh} / \mathrm{month}$ and $10800 \mathrm{kWh} /$ year. In terms of costs, this energy saving can generate each month $152,80 \mathrm{USD}(900 \mathrm{kWh} \times 0.169 \mathrm{USD})$ or each year 1883,6 USD. A good management of the system of lighting can generate energy saving and costs in the base station Missinguileo.

8.2. Application of Proposals of Energy Savings on the Maroua Market Site. While applying the proposals of an energy savings proposed, we followed the variation of the total energy consumption of the site during the days from the 16th to 18th July 2012. The results obtained are recapitulated in Table 10 and the histogram is represented in Figure 13, establishing the comparison between the day of Monday 9th July 2012 (where the proposals of energy savings were not yet applied) and days from the 16th to 18th July 2012 (application of proposals for an energy saving). This histogram (Figure 13) shows that the energy consumption (consumption from 6:00 am to 6:00 pm, consumption from 6:00 pm to 6:00 am, average consumption per hour, and total average consumption per day) recorded on the $09 / 07 / 2012$ is higher than that recorded from the 16 th to 18th July 2012.

The average power consumption from the 16th to 18th July 2012 is $53 \mathrm{kWh} /$ day. 
TABLE 9: Comparison between energy consumption of the site, case of a day not applying the proposals of energy savings (06/07/2012), case of a day for which the air conditioner was under failure, and case of days applying the proposals of energy savings (16, 17, and 18 July 2012): Missinguileo site.

\begin{tabular}{|c|c|c|c|c|c|}
\hline Dates & $\begin{array}{c}\text { Energy } \\
\text { consumption } \\
\text { (kWh) from } \\
6 \text { am to } 6 \mathrm{pm}\end{array}$ & $\begin{array}{c}\text { Energy } \\
\text { consumption } \\
(\mathrm{kWh}) \text { from } \\
6 \mathrm{pm} \text { to } 6 \mathrm{am}\end{array}$ & $\begin{array}{c}\text { Average } \\
\text { energy } \\
\text { consumption } \\
\text { (kWh) per } \\
\text { hour }\end{array}$ & $\begin{array}{l}\text { Total energy } \\
\text { consumption } \\
(\mathrm{kWh}) \text { daily }\end{array}$ & $\begin{array}{c}\text { Energy } \\
\text { savings } \\
\text { realized, by } \\
\text { the reference } \\
\text { date } \\
(06 / 07 / 2012)\end{array}$ \\
\hline 06/07/2012 & 70 & 53 & 5,125 & 123 & - \\
\hline $11 / 07 / 2012$ & 35,6 & 34 & 2,9 & 69,6 & $\begin{array}{c}53 \mathrm{kWh} \text { or } \\
43,41 \%\end{array}$ \\
\hline $16 / 07 / 2012$ & 46,2 & 46,6 & 3,86 & 92,8 & $\begin{array}{c}30,2 \mathrm{kWh} \text { or } \\
24,55 \%\end{array}$ \\
\hline $17 / 07 / 2012$ & 45,3 & 46,8 & 3,84 & 92,1 & $\begin{array}{c}30,9 \mathrm{kWh} \text { or } \\
25,12 \%\end{array}$ \\
\hline $18 / 07 / 2012$ & 46,9 & 46,3 & 3,88 & 93,2 & $\begin{array}{c}29,8 \mathrm{kWh} \text { or } \\
24,22 \%\end{array}$ \\
\hline
\end{tabular}

TABLE 10: Comparison between the energy consumption of the site, case of a day not applying the proposals of energy savings (09/07/2012) and case of days applying the proposals of energy savings (16, 17, and18 July 2012): Maroua Market site.

\begin{tabular}{|c|c|c|c|c|c|}
\hline Dates & $\begin{array}{c}\text { Energy } \\
\text { consumption } \\
\text { (kWh) from } \\
6 \text { am to } 6 \mathrm{pm}\end{array}$ & $\begin{array}{c}\text { Energy } \\
\text { consumption } \\
(\mathrm{kWh}) \text { from } \\
6 \mathrm{pm} \text { to } 6 \mathrm{am}\end{array}$ & $\begin{array}{c}\text { Average } \\
\text { energy } \\
\text { consumption } \\
\text { (kWh) per } \\
\text { hour }\end{array}$ & $\begin{array}{l}\text { Total energy } \\
\text { consumption } \\
(\mathrm{kWh}) \text { daily }\end{array}$ & $\begin{array}{c}\text { Energy } \\
\text { savings } \\
\text { realized, by } \\
\text { the reference } \\
\text { date } \\
(09 / 07 / 2012)\end{array}$ \\
\hline 09/07/2012 & 33 & 29 & 2,58 & 62 & - \\
\hline $16 / 07 / 2012$ & 28,4 & 25,6 & 2,25 & 54 & $8 \mathrm{kWh}$ or $13 \%$ \\
\hline 17/07/2012 & 28,1 & 25,2 & 2,22 & 53,3 & $\begin{array}{c}8,7 \mathrm{kWh} \text { or } \\
14 \%\end{array}$ \\
\hline $18 / 07 / 2012$ & 27,8 & 25 & 2,2 & 52,8 & $\begin{array}{c}9 \mathrm{kWh} \text { or } \\
14,83 \%\end{array}$ \\
\hline
\end{tabular}

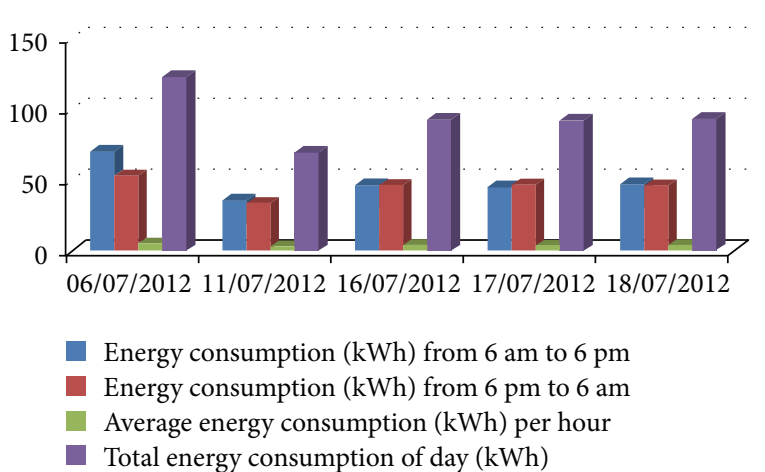

Figure 12: Comparison between energy consumption of the site, case of a day not applying the proposals of energy savings $(06 / 07 / 2012)$, case of a day for which the air conditioner was under failure and case of days applying the proposals of energy savings (16, 17, and 18 July 2012): Missinguileo site.

It is lower than that of the day of the $09 / 07 / 2012$ (62 $\mathrm{kWh} /$ day), which is $9 \mathrm{kWh} /$ day, or $270 \mathrm{kWh} / \mathrm{month}$, or

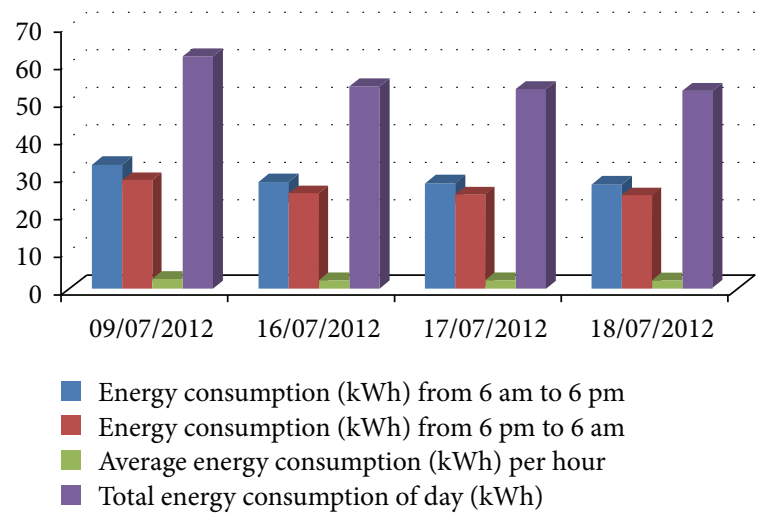

FIGURE 13: Comparison between the energy consumption of the site, case of a day not applying the proposals of energy savings $(09 / 07 / 2012)$ and case of days applying the proposals of energy savings (16, 17, and 18 July 2012): Maroua Market site.

$3240 \mathrm{kWh} /$ year, or $14.5 \%$ of energy saving realizable. In terms of saving costs, it is $45,84 \mathrm{USD} /$ month or $550,10 \mathrm{USD} /$ year. 
TABLE 11: Techniques of solutions of energy efficiency.

\begin{tabular}{|c|c|}
\hline $\begin{array}{l}\text { Base station equipment, } \\
\text { energy savings potential }\end{array}$ & Technical proposals of energy savings \\
\hline Lighting systems & $\begin{array}{l}\text { (i) Having the light level detectors in areas containing the base stations; } \\
\text { (ii) Using more efficient lighting lamps to contribute to the reduction of cooling load; } \\
\text { (iii) Replacing nonfunctional lighting lamps to ensure visual comfort of the user. }\end{array}$ \\
\hline Air conditioner system & $\begin{array}{l}\text { (i) Better air conditioner system adapting to the energy demand; } \\
\text { (ii) Delay the start of the air conditioning units to avoid current peaks; } \\
\text { (iii) Set the appropriate temperature and humidity inside the rooms, from } 19^{\circ} \mathrm{C} \text { to } 30^{\circ} \mathrm{C} \text { and } 75 \% \\
\text { to } 52 \% \text { (thermal comfort in the Sahel [8]); } \\
\text { (iv) Have the switcher time, on air conditioners lines (especially during cold periods, running } \\
\text { from } 9 \text { am to } 5 \text { pm, meaning that air conditioners operate from } 9 \text { am to } 5 \text { pm during cold periods); } \\
\text { (v) Avoid placing the air conditioner condensers in direct sunlight } \\
\text { (vi) If possible, instead of air conditioners, have fans (with variable speed) which can recover heat } \\
\text { or having outdoor BS, thus deleting conditioners and ventilators. }\end{array}$ \\
\hline
\end{tabular}

(i) Windows must be in good seal;

(ii) The windows should be wide so we can take advantage of wide daylight to reduce energy

Locations of windows' consumption due to lighting lamps;

rooms

(iii) The windows locations are important on the internal temperature of the rooms (better South or North), if they are facing east or west they contribute to either rising temperature of the room (the sun hitting the windows) or cooling the room (shading phenomenon).

(i) Having BTS and transmission equipment which are energy efficient;

(ii) Having the BTS and transmission equipment that can switch off during periods of low traffic;

Base transmitter station and others equipment

(iii) The BTS and other transmission equipment being as near as possible to the transmitting antennas (the compact BS or distributed architecture BS);

(iv) Equipment placing in the open air (outdoor base station) being less energy consumers;

(v) Using the AC/DC converters and current stabilizer having an effectiveness about $95 \%$.

\begin{tabular}{ll}
\hline Cables connections & The energy losses from cables must be less as possible. \\
\hline Power supply & (i) The better power supply adapting to the energy load; \\
(ii) Control and monitor energy consumption using "smart meters."
\end{tabular}

The applications of the proposals of an energy saving which we carried out in the three sites of the base stations show us that energy saving is realizable (in a few days) when we operate on the lighting system and air conditioning system. If we apply those proposals in for one month or a year, the results will be more visible.

To reduce indeed the power consumption in the base station of telecommunication, we proposed a technical description of solutions being able to vigorously make the base stations located in the Sahel zone more effective.

\subsection{Technical Description of Solutions of Energy Efficiency} (Energy Savings) Proposed in Base Stations Situated in the Sahel Zone of Cameroon. We describe in Table 11 a set of recommendations to be able to realize energy savings in a base station situated in the Sahel zone.

\section{Conclusions}

In this paper, we have presented some approaches of energy savings and power consumption on the sites of the base stations of Telecommunication recently encountered in literature review of research based on the energy efficiency of the mobile communication. Moreover, in the Sahel zone, according to the average power consumption per/month, we met three categories of the base stations of telecommunication for which we have carried out energy audits. These audits reveal wasting of energy, and the proposals and application of some techniques of energy saving have enabled recording energy saving and considerable costs. The energy model proposed is more complete since it takes into account all the equipment consuming energy of the base station. To further reduce the expenditure in energy consumption of telecommunication base stations in the Sahel zone and the emission of greenhouse gases, in addition to the installation of measurements of energy efficiency, it is necessary to conduct a comparative study to know if the use of renewable energy sources is technically and economically profitable.

\section{Nomenclature}

ICTs: Information and communication technologies

AC: Alternative current

E: Power consumption

TV: Television

RFI: Radio France International 
ADM: $\quad$ Add drop multiplexing

AES-Sonel: Apply Energy Services-Sonel (société nationale d'électricité)

ASIC: Application-specific integrated circuit

BSC: $\quad$ Base station controller

BTS: $\quad$ Base transceiver station

CAMTEL: Cameroon telecommunication

CDMA: Code division multiple Access

USD: $\quad$ United states Dollar

$\mathrm{CO}_{2}$ : $\quad$ Dioxyde of carbone

CRTV: $\quad$ Cameroon radio and television

DC: $\quad$ Direct current

DSP: $\quad$ Digital Signal Processor

EDGE: Enhanced Data rates for GSM Evolution

EGPRS: Enhanced GPRS

FPGA: Field-programmable gate array

GaAs: Gallium arsenide

GES: $\quad$ Gaz à effet de serre

GPRS: $\quad$ General Packet Radio Service

GSM: Global System for Mobile Communications

HSCSD: High Speed Circuit Switched Data

ISO: Organisation internationale de normalisation

LTE: Long-Term Evolution

MSC: $\quad$ Mobile services switching centres

MTN: Mobile telephone network

PSU: $\quad$ Power supply unit

RU: $\quad$ Radio unit

RBU: $\quad$ Radio base units

RF: $\quad$ Radio fréquence

RX: $\quad$ Receiver

Si: $\quad$ Silicium

TIC: $\quad$ Technologie de l'information et de la communication

TRI: $\quad$ Temps sur retour d'investissement propre

TWh: $\quad$ Tera watt hour

TX: $\quad$ Transmitter

UIT: Union internationale des télécommunications

UMTS: Universal Mobile Télécommunications System

VSAT: $\quad$ Very small aperture terminal

WIMAX: Worldwide Interoperability for Microwave Access.

\section{Competing Interests}

The authors declare that there are no competing interests regarding the publication of this paper.

\section{Acknowledgments}

The authors express their kindly acknowledgment of mobile communication and audiovisuals companies (CAMTEL, ORANGE, MTN, and CRTV) represented in the northern part of Cameroon.

\section{References}

[1] Fond d'Energie Rurale, 2010, http://www.se4all.org/sites/ default/files/Cameroon_RAGA_FR_Released.pdf.
[2] http://www.afriquinfos.com/articles/2012/5/26.

[3] I. Humar, X. Ge, L. Xiang, M. Jo, M. Chen, and J. Zhang, "Rethinking energy efficiency models of cellular networks with embodied energy," IEEE Network, vol. 25, no. 2, pp. 40-49, 2011.

[4] Ericsson, "Sustainable energy use in mobile communications," Ericsson White Paper, 2007.

[5] Le rapport TIC et Développement Durable, 2008, http://www .ladocumentationfrancaise.fr/var/storage/rapports-publics/ 094000118.pdf.

[6] A. Conte, "Power consumption of base stations," in Proceedings of the TREND Plenary Meeting, Ghent, Belgium, February 2012.

[7] Study Energy Efficient Radio Acess Network Technologies, "Alcatel-lucent/TU dresden vodafone chair mobile communications systems," ATIS Report on Wireless Network Energy Efficiency, 2009.

[8] T. Chen, Y. Yang, H. Zhang, H. Kim, and K. Horneman, "Network energy saving technologies for green wireless access networks," IEEE Wireless Communications, vol. 18, no. 5, pp. 3038, 2011.

[9] J. Lorincz, T. Garma, and G. Petrovic, "Measurements and modelling of base station power consumption under real traffic loads," Sensors, vol. 12, no. 4, pp. 4281-4310, 2012.

[10] H. Hirata, K. Totani, T. Maehata et al., "Development of high efficiency amplifier for cellular base stations," SEI Technical Review, no. 70, pp. 47-52, 2010.

[11] S. Zoican, "The role of programmable digital signal processors (dsp) for 3 g mobile communication systems," Acta Technica Napocensis, vol. 49, pp. 49-56, 2008.

[12] S. N. Roy, "Energy logic: a road map to reducing energy consumption in telecom munications networks," in Proceedings of the 30th International Telecommunications Energy Conference (INTELEC '08), pp. 1-9, IEEE, San Diego, Calif, USA, September 2008.

[13] M. Etoh, T. Ohya, and Y. Nakayama, "Energy consumption issues on mobile network systems," in Proceedings of the International Symposium on Applications and the Internet (SAINT '08), pp. 365-368, Turku, Finland, August 2008.

[14] J. Lorincz, T. Garma, and G. Petrovic, "Measurements and modelling of base station power consumption under real traffic loads," Sensors, vol. 12, no. 4, pp. 4281-4310, 2012.

[15] L. M. Correia, D. Zeller, O. Blume et al., "Challenges and enabling technologies for energy aware mobile radio networks," IEEE Communications Magazine, vol. 48, no. 11, pp. 66-72, 2010.

[16] A. Conte, A. Feki, L. Chiaraviglio, D. Ciullo, M. Meo, and M. A. Marsan, "Cell wilting and blossoming for energy efficiency," IEEE Wireless Communications, vol. 18, no. 5, pp. 50-57, 2011.

[17] O. Blume, H. Eckhardt, S. Klein, E. Kuehn, and W. M. Wajda, "Energy savings in mobile networks based on adaptation to traffic statistics," Bell Labs Technical Journal, vol. 15, no. 2, pp. 77-94, 2010.

[18] C. Han, T. Harrold, S. Armour et al., "Green radio: radio techniques to enable energy-efficient wireless networks," IEEE Communications Magazine, vol. 49, no. 6, pp. 46-54, 2011.

[19] E. Oh, B. Krishnamachari, X. Liu, and Z. Niu, "Toward dynamic energy-efficient operation of cellular network infrastructure," IEEE Communications Magazine, vol. 49, no. 6, pp. 56-61, 2011.

[20] D. Tripper, A. Rezgui, P. Krishnamurthy, and P. Pacharintankul, "Dimming cellular networks," in Proceedings of the IEEE Global Telecommunications Conference (GLOBECOM '10), pp. 1-6, Pittsburgh, Pa, USA, December 2010. 
[21] Z. Niu, Y. Wu, J. Gong, and Z. Yang, "Cell zooming for cost-efficient green cellular networks," IEEE Communications Magazine, vol. 48, no. 11, pp. 74-79, 2010.

[22] Z. Niu, “TANGO: traffic-aware network planning and green operation," IEEE Wireless Communications, vol. 18, no. 5, pp. 2529, 2011.

[23] M. A. Marsan and M. Meo, "Energy efficient management of two cellular access networks," ACM SIGMETRICS Performance Evaluation Review, vol. 37, no. 4, pp. 69-73, 2010.

[24] Senza Fili Consulting, "White Paper 2010," http://www.senzafiliconsulting.com.

[25] N. Faruk, A. A. Ayeni, M. Y. Muhammad et al., "Powering cell sites for mobile cellular systems using solar power," International Journal of Engineering and Technology, vol. 2, no. 5, 2012. 

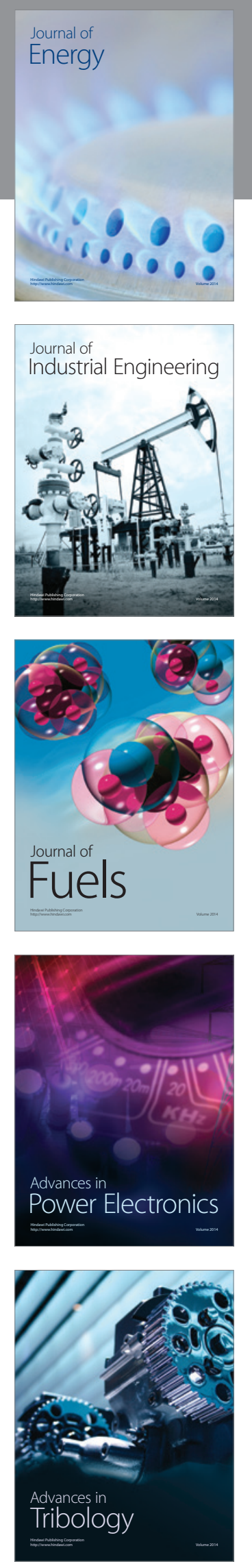
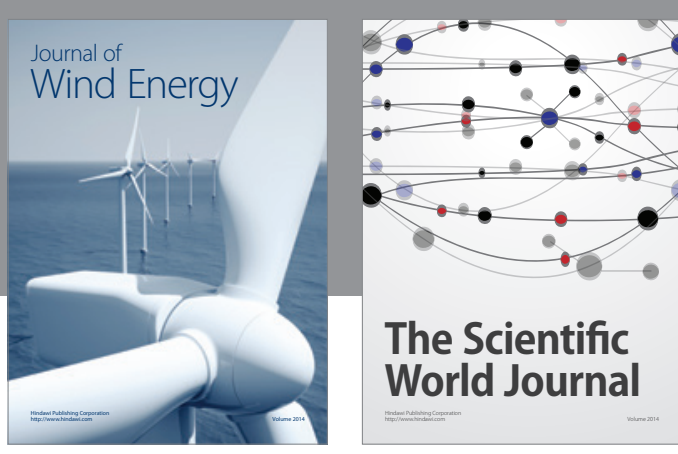

The Scientific World Journal
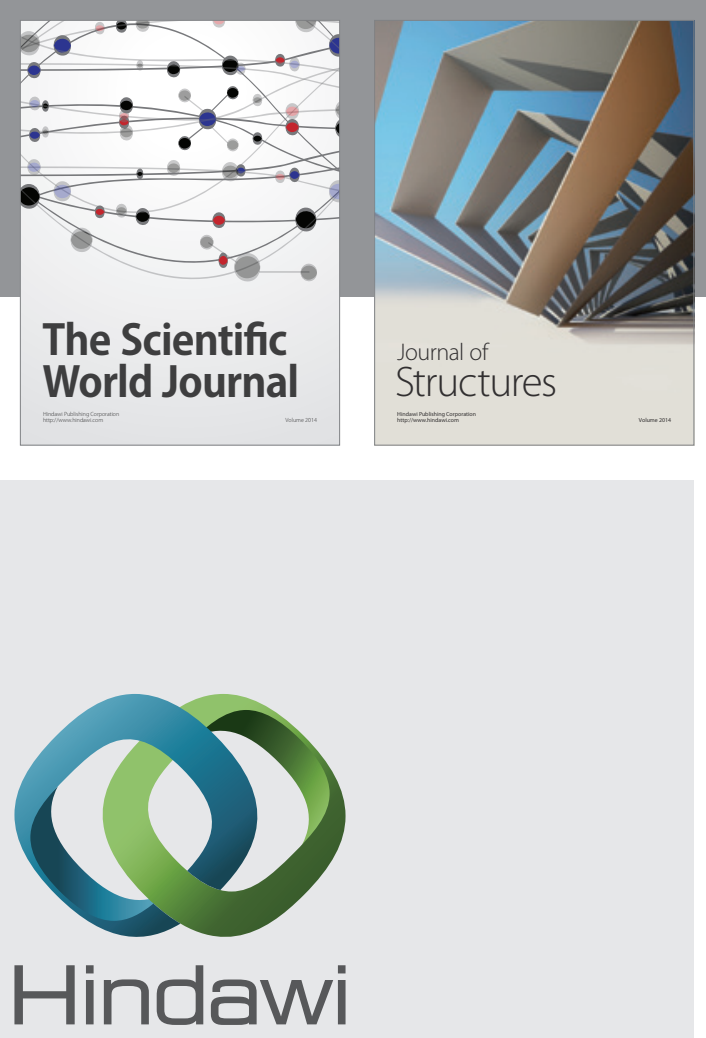

Submit your manuscripts at

http://www.hindawi.com
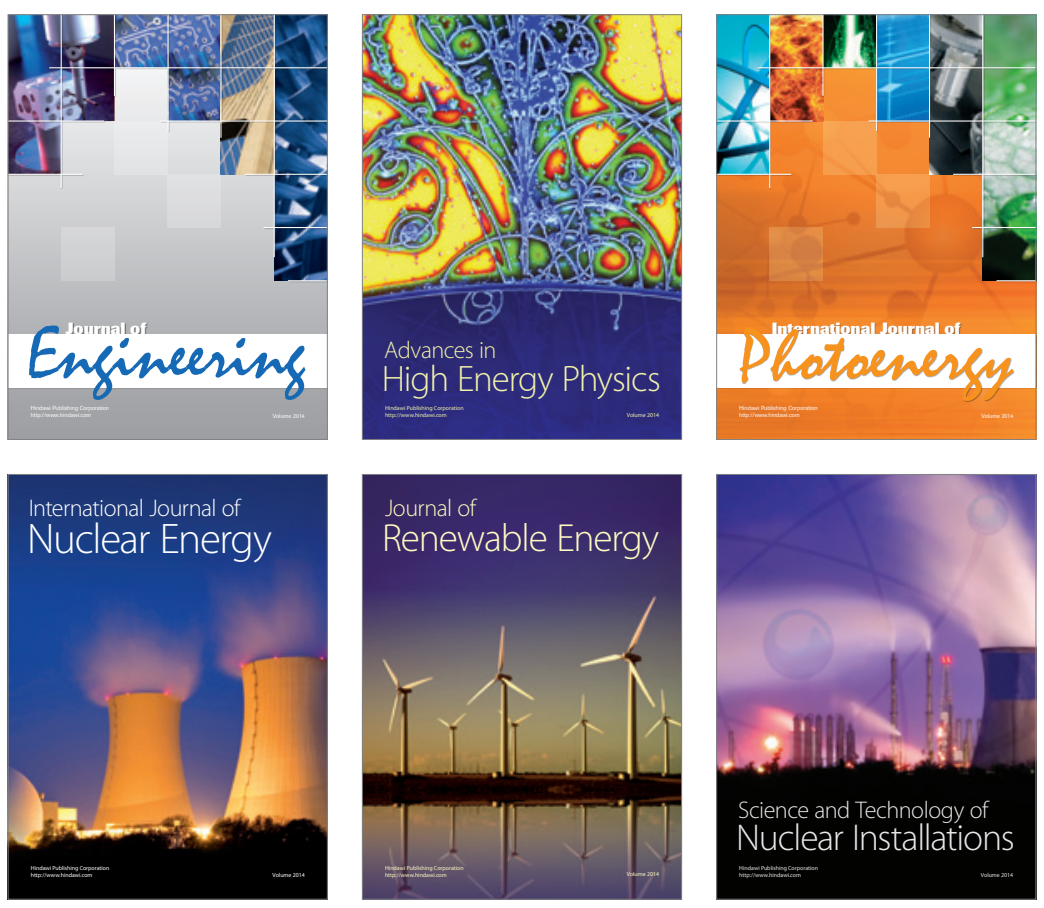
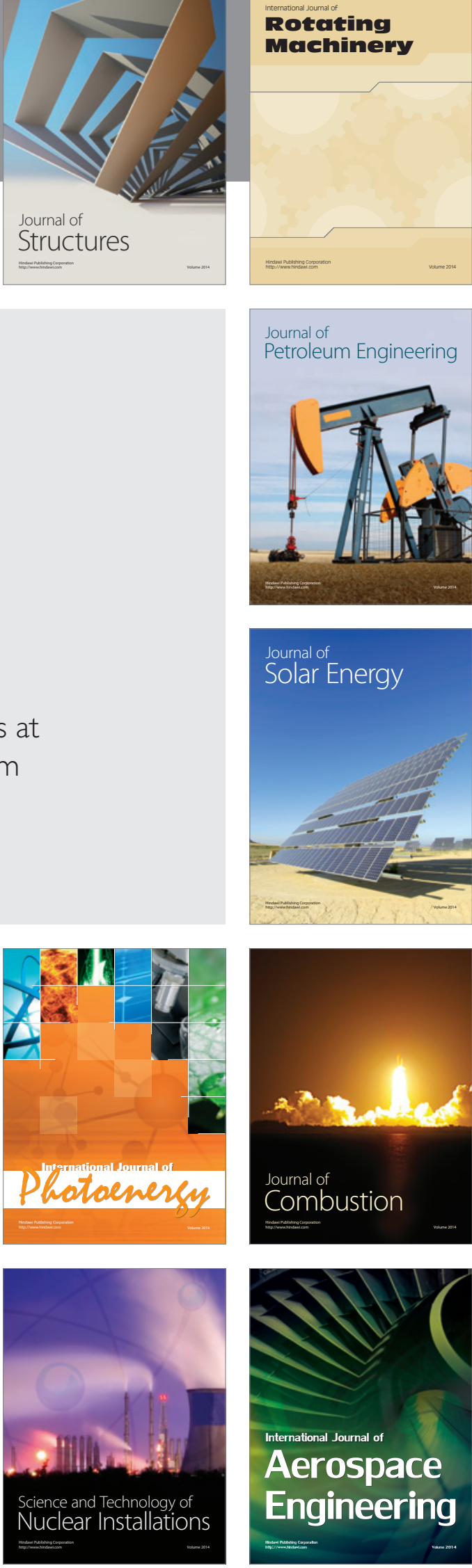